1

With or Without Blood / Avec ou sans sang 


\title{
Does Blood Have Gender in Jewish Culture?
}

\section{David Biale}

La recherche récente concernant le sang dans la tradition juive met l'accent sur l'opposition des genres: le sang masculin (celui de la circoncision ou du sacrifice) représente le contrôle, et le sang féminin (celui des menstruations) l'absence de contrôle. Toutefois, une lecture précise du traitement fait au sang dans la Bible juive, la littérature rabbinique et le mysticisme médiéval montre que le rapport entre le sang et le genre sexuel est complexe et qu'il dépend de l'histoire.

In the late-thirteenth or early-fourteenth century, an Ashkenazic author compiled a series of biblical exegeses and other arguments that might be used in polemics against Christians. Modifying some early midrashim, themselves originating possibly as anti-Christian polemics, he tried to undo the Christian use of the blood of the paschal lamb as a prefiguration of Jesus. Thus, he wrote on Exodus 12:

\begin{abstract}
"And they shall take of the blood" [Exod. 12: 7] refers to three drops: "Put it on the lintel" - one, "and on the two sideposts" - two. This refers to three bloods - [the blood of the paschal lamb], the blood of circumcision, and the blood of the menstruan. (Berger 53)
\end{abstract}

Both Christians and Jews understand the blood on the doorposts not just as apotropaic, but as redemptive. What draws our attention here is that female blood (the blood of menstruation) is given the same power and positive valence as male blood (the blood of circumcision).

This startling text, to which I will return several times, raises the question of the "gendering" of blood in Jewish culture: does blood have gender and, if so, what does it mean? In the 1980s, Nancy Jay made the opposition between the blood of childbirth and the blood of sacrifice the cornerstone of her theory of patriarchal religion, of which the Bible is a key instance: through the blood of sacrifice, men gain 
control over lineage, which might otherwise fall into the hands of women, whose claim would lie in the bleeding of childbirth. Following Jay, Howard Eilberg-Schwartz and Leonie Archer independently argued that female blood - the blood of menstruation and childbirth - is associated with pollution because it is uncontrolled bleeding, while male blood or blood spilled by men - the blood of circumcision and animal sacrifices - is controlled and, if spilled properly, does not pollute. The first represents nature, the second culture. A few years later, Lawrence Hoffman applied this structuralist distinction to his study of the blood of circumcision in rabbinic literature, arguing that the same gender hierarchy pertained in that stratum of ancient Judaism. One might say that a certain consensus has emerged around gender and blood in Jewish culture: the blood controlled by men establishes covenant, purity and patriarchy, while the uncontrolled bleeding of women threatens this order and is relegated to the realm of impurity.

It is this consensus that I wish to examine critically in the pages that follow. While some of the argument will remain persuasive, it will also require considerable modification and nuancing. I am especially unconvinced of the nature-culture dichotomy that these authors have adopted whole cloth from the famous essay of Sherry Ortner, "Is Female to Male as Nature Is to Culture?" While Hoffman quite rightly agrees with Ortner's critics that the nature-culture dyad is itself a cultural product and therefore hardly universal, he goes on to say that it does characterize rabbinic culture. Yet, this conclusion seems to me very much open to question. Neither biblical nor rabbinic culture can be said to view nature as the realm of uncontrolled (female) forces that must be tamed by (male) religion. Insofar as God is the ruler of the whole world, nature remains under His domain, albeit with distinctions such as land which is holy versus land which is not, as well as desert regions devoid of human habitation. Women are as much the creation of God as are men (indeed, the first creation story in Genesis states that both reflect God's image).

This is not the place to elaborate on biblical and rabbinic notions of nature, which are subjects unto themselves. It is sufficient to point out that the nature-culture dichotomy requires a much more thoroughgoing analysis of what these terms might mean in their Jewish contexts than the authors I have mentioned have offered. To say, for example, with Hoffman, that men are expected to control their sexuality (Hoffman brings midrashim about Joseph as the paradigmatic case of self-control), does not prove that "culture" is associated with male sexual control while "nature" is the realm of wild, uncontrolled female 
sexuality. Indeed, statements in rabbinic literature about male self-control are not matched, except through the most speculative exegesis, with statements that women are uncontrolled: this is a modern inference read back into the texts.

All rituals, such as circumcision and sacrifice are, by definition, controlled, while physiological processes, such as childbirth and menstruation, are uncontrolled. The fact that childbirth and menstruation are female tells us very little about whether Jewish culture associated women with "uncontrolled nature." Consider, for example, the contrast between Esau and Jacob in both the Bible and later Jewish literature: Esau clearly represents the wild man of nature, but it is Jacob, the one "who sits in tents," who is arguably both "feminine" and cultured. In addition, not everything uncontrolled creates pollution: sweat, whether originating on a male or female body, has no such consequence, nor, as we shall see, does bleeding from a wound. We may provisionally conclude that the syllogism male is to culture as female is to nature is quite forced in the Jewish context.

Once we set aside such preconceptions, we can return to the texts on gender and blood with fresh eyes. In the pages that follow, I will take up texts from four distinct genres: biblical law, rabbinic midrash, medieval/early modern Kabbalah and, returning to the subject with which we began, medieval polemics. Each of these reveals different aspects of the relationship between gender and blood in ways that will complicate the dichotomies that have been overly simplified in recent scholarship.

\section{Biblical Blood}

Jacob Milgrom has offered perhaps the most comprehensive survey of biblical blood in a variety of articles, with the results summed up in his magisterial Anchor Bible Commentary on Leviticus. In this survey, Milgrom presents a detailed argument for why the Levitical laws consider menstrual blood polluting. Since blood stands for life, Milgrom reasons that menstrual blood, together with semen, a human corpse and scale disease, are defiling because they are out of place: "their common denominator is death" (Leviticus 1-16, 1002). Death is the archetypical impurity and anything associated with it is polluting, albeit usually to a much lesser degree.

There is, however, a significant problem in Milgrom's argument that menstrual blood creates impurity. Notice that only blood from the genitals, like semen or pathological genital discharges, is polluting. All other blood, including human blood, does not pollute. While human 
blood spilled through violence can pollute the land (Numbers 35: 33) and animal blood improperly disposed of creates a form of bloodguilt (dam yehashev), neither of these falls directly under the laws of cultic purity and impurity: a murderer may receive the death penalty and someone who slaughters an animal without proper blood rituals may be "cut off" (karet), but nowhere is it stated that he or she is prohibited from entering a cultic site to bring a sacrifice (not that it will do them much good, since bringing an atonement sacrifice for these intentional crimes will not expiate them). So, if impurity is associated with death, it would be hard to explain why only menstrual blood, and not any other kind of blood, creates impurity. On the contrary, simple observation would show that women do not die from menstrual bleeding, while blood from a wound, if severe enough, may well turn its victim into a corpse.

Menstrual blood should not, therefore, be considered in either the same category as other kinds of blood or as necessarily connected to death. Neither should it be considered, as Mary Douglas does, a form of dirt, that is, "matter out of place" (Douglas 35-36). As Milgrom points out, Douglas was wrong in arguing that impurity in the Bible is dirt, since many substances that would be considered dirty - such as urine, feces or spit - do not create impurity. And, in fact, Douglas' whole hypothesis becomes problematic when considering semen that is ejaculated by the male into the female: according to Lev. 15: 18, both parties must bathe and are rendered impure until evening, even though the semen is anything but "out of place."

Milgrom and Eilberg-Schwartz are both aware of this peculiarity of biblical law, but neither is fully cognizant of the difficulty it poses for the argument that male and female blood are fundamentally different. A promising attempt to do so has been made by Leslie A. Cook in an essay on women's rituals of purification in the Bible and Mishna. Cook correctly notes that "both men's and women's discharges can generate impurity in certain contexts. The defining factor seems to be not whose blood - not even blood - but rather the context of the discharges" (50). Women's blood is not valued differently from men's blood (and semen should be included here), nor from animal blood. Blood can be used to purify, in the right context, or can create impurity in the wrong context. But blood itself is neither pure nor impure. The role of blood, Cook argues, is to distinguish human beings from God. Since God is said to "eat" blood, human beings are not allowed to eat it and, therefore, a portion or all of different sacrifices is reserved for Him. 
Virtually all the scholarly literature assumes that the defiling character of genital discharges, healthy or pathological, means that they must be associated with something negative, such as death or loss of potential life. I would like to suggest a thought experiment: let us try to imagine what it would look like if menstrual blood and semen were not viewed as inherently negative (although clearly - and for reasons we will discuss - the various biblical texts seem to regard menstrual blood or the state of menstruation as much more problematic, if not more dangerous, than semen).

Here, Greek sources may provide some useful analogies. As Helen King has demonstrated, for Hippocrates, menstrual blood was analogous to the blood of a sacrificial animal. The medical logic behind this comparison is that menstrual blood is humorally hot, like the blood that spurts from the throat of an animal. In Aristotle, the psyche or spirit of life is contained in this hot blood. As King has argued, for the Greeks, a woman (gyne), as opposed to a virgin (parthenos), is defined by bleeding, while a mature woman who does not bleed regularly was considered ill. Men, on the other hand, are not defined by bleeding, but by the opposite: shedding blood in war or in sacrifices. The alignment of mature women with sacrificial victims in Hippocratic body symbolism presents "their bleeding as an essential part of the life of the city" (King 76). For, just as men sustain the city by their blood-letting activities, so women contribute to the city's fertility by their own form of bleeding. The gods, however, fall outside of these activities, for they have no blood and therefore do not bleed. Artemis, the goddess of the hunt and of fertility, is a particular example of this divine difference: she does not bleed, but she sheds the blood of others, both as huntress and as director of the process by which a parthenos becomes a gyne.

Until the hellenistic period, Greek sources did not treat menstrual bleeding as ritually polluting, as opposed to the blood of childbirth, which did prevent one from entering a sacred precinct. It would be a mistake, though, to associate either the blood of childbirth or menstruation with death, which also caused ritual defilement in Greek religion. Quite to the contrary: again following King, both of these forms of female bleeding are part of the natural order and are necessary elements of fertility. Greek religion assured fertility by assiduously segregating the holy from the profane: Artemis remains a virgin, as do her devotées, but, by doing so, they guarantee that profane sexuality will be fertile. For the same reason, sexual intercourse may not take place within a Greek temple (Herodotus claimed that only the Greeks and Egyptians refrain from sex within their temples: he left out the 
Israelites). That which is part of the natural order belongs in the profane world; the sacred world, where humans commune with the gods, must be free of such activities, not because they are inherently devalued, but because they are quintessentially human.

In the Bible, too, an act of intercourse causes defilement, a puzzle, unless we think of sexual relations as precisely those which, ordained by God, may not take place in His sanctuary. Sexuality and everything connected to it belong to the profane world, as they do in Greek religion. Moses therefore tells the people to separate from their wives for three days before receving the Torah at Sinai (Exodus 19: 15) and one of the leitmotifs of the prophetic literature is the denunciation of practices (real or imaginary) that involve sexual relations in cultic sites.

How might this thinking apply to the ban on sex with a menstruant? If menstrual blood was conceived of, like semen, as a procreative fluid, then it, too, had to be separated from cultic activity. And, intercourse during a woman's menstrual period might produce a double impurity. Indeed, this appears to be the reasoning behind the most stringent form of the prohibition in Lev. 20: 18: "If a man lies with a woman in her infirmity (davah) and uncovers her nakedness, he has uncovered her source (meqorah) and she has uncovered the source of her blood; both of them shall be cut off (ve-nikhretu) from among their people." The "source" of the blood is what must remain hidden, as it apparently is when she is not menstruating, even during intercourse. Menstrual bleeding by itself indicates that the source has been breeched, but it takes an act of intercourse to fully "reveal" it. This "revealing" (gilui) is therefore at once related to, but also different from, the other sexual prohibitions in which gilui means simply sexual relations. What is clear is that intercourse during the menses causes both partners to "reveal" (or, come into contact with) the source of female fertility. And the punishment of karet ("cut off from their people") for this infraction may be infertility, if we are to follow the interpretation of Baruch Levine (Excursus 1).

As in Greek religion, so in ancient Israel, fertility is assured by segregating the holy from the profane: no sex is allowed in sacred sites. God may be the source of fertility, but He does not engage in sexual relations, as do the gods of the Canaanites, and therefore one must not have sex in the divine precinct, as the prophets thought that the Canaanites did. Would it be too speculative to suggest that the same logic applies to sexual contact with the female source of fertility? The blood of menstruation, is, in a sense, a divine fluid, more sacred than normal blood. For that reason, following Mary Douglas, female 
genital blood is a site of danger and impurity, but also of power. If, again to follow Douglas, the body mirrors society, then the female body contains a sacred site. Like the profane "encroacher" who enters a cultic site and must be killed (Numbers 1: 51), so those who engage in sex during menstruation encroach on sacred terrain and must suffer the appropriate punishment.

This theory of the meaning of the female body has an analogy in the beliefs of the Hua of the New Guinean highlands, as described by Anna Meigs: "The site of the body is the temple, the place where the awesome powers reside" (128). This is because the Hua do not have any particular theology: with no gods to be worshipped, the spiritual forces in the world are to be found in the body. This is a view that resonates with rabbinic Judaism, for whom the destruction of the Temple meant the end of God's direct connection to the world, thus leaving the body as the Temple's remnant. For the Hua, the blood of menstruation and childbirth are viewed at once as the most polluting and the most creative bodily substances. The argument I am proposing here suggests a similar dynamic in biblical religion: the polluting character of menstrual blood is a result of its sacred power, which comes from a sacred site within the female body.

This conclusion fits quite well with the representation in Ezekiel (as well as other of the literary prophets) of Israel as a woman, one who repeatedly defiles herself with foreign men, but whose true husband is God. Adultery is akin to sex during menstruation because, in both cases, the source of Israelite fertility is "revealed" to those to whom it should be forbidden. Ezekiel conflates menstruation, violent bloodshed and idolatry:

O mortal, when the House of Israel dwelt on their own soil, they defiled it with their ways and their deeds; their ways were in My sight like the impurity of a menstruous woman. So I poured out My wrath on them for the blood which they shed upon their land and for the fetishes with which they defiled it. (16: 17-18)

Ezekiel repeatedly and explicitly describes the idolatrous practices of Israel in terms of cultic sex: "you made yourself phallic images and fornicated with them" (16: 17) Thus, the sins of the Israelites involve the violation of the sexual boundary between the holy and the profane. If sex during menstruation was also seen as a violation of this boundary, it would make sense that Ezekiel - a priest of the period of the 
Exile - would compare Israel to a menstruous woman.

Similarly, when Ezra, also a priest, discovers that the returnees from Babylonia have been intermarrying with the "peoples of the land," he says "the land that you are about to possess is a menstruous land, unclean (eretz niddah) through the menstruousness of the peoples of the land (be-niddat amei ha-aratzot), throughout their abhorrent practices with which they, in their impurity, have filled it from one end to the other (9: 11)." Ezra then bans marriages with these "foreigners" (who may actually have been Israelites who did not go into exile) on essentially "racial" grounds: "the holy seed (zera" kodesh) has become intermingled with the peoples of the land" (9: 2). The holy seed must be protected from contact with the impurity of menstruation, invoked here as a metaphor for impurity in general, but an apt metaphor since it is precisely the kind of impurity that might be acquired during sexual relations.

I do not mean to try to exonerate Ezekiel, Ezra and the authors of the Holiness Code from a negative portrayal of menstruation (Ezekiel in particular was an overtly misogynistic writer). But I do want to suggest that, first, menstrual blood is not really like any other blood and, second, that the impurity of menstruation is linked to a source that may be considered sacred and to processes that the priests celebrated, even as they, like their Greek counterparts, sought to keep them out of the cultic sphere. Menstruating women served the priestly cause of Israelite fertility, but, for that reason, their cyclical physiology had to be regulated and segregated from the divine. In a late stage of biblical religion (between the last century of the First Temple period and the sixth and fifth centuries), what had been a largely technical distinction between purity and impurity became the source of loaded moral judgments, the consequences of which remain with us today. But if the weight of these judgments seems to have come down disproportionately on female bleeding, it should not obscure the fact that, at its origins, the primary distinction was less between male and female genital discharges than between those fluids emitted from the genitals versus blood from elsewhere in the body. Gender was not originally the primary determinant of biblical blood.

\section{Rabbinic Gender-Bending}

In his application of anthropology to the Bible, Howard EilbergSchwartz argued that the priestly literature set the blood of circumcision against the blood of menstruation: the first a controlled bleeding ("the fruitful cut," as he puts it), the second uncontrolled. As I have 
already suggested, there is little in the biblical account to support his dichotomy. While sacrificial blood was, in fact, deliberately spilled and then became, as Milgrom describes it, a ritual "detergent" for purifying the cultic site from the "miasma" of impurity, this blood, as we have seen, has nothing to do with blood from either male or female genitals. Moreover, with the exception of the enigmatic "bridegroom of blood" episode in Exodus 4, the blood of circumcision plays no role in the Bible. It has no cultic meaning, nor do we learn anywhere whether it is pure or impure (the inference from elsewhere would suggest that it has no relationship to the impurity of genital discharges). Whatever one might want to argue about the meaning of menstrual blood in the Bible, a structuralist binary opposition between male and female blood is simply not to be found there.

A few years ago, Lawrence Hoffman suggested that the rabbis took over the ritual of circumcision, which in its priestly expression had established both patriarchy and Israelite exclusivity, and added blood to it. In Hoffman's account, the rabbinical idea of covenant was founded on blood - specifically, the blood of circumcision. There is, in fact, a great deal of material to support this argument. A text from the early rabbinic period, the Targum Jonathan, translates Exodus 12: 13 (the source for our medieval polemical text quoted above): "Let this blood [i.e. the blood of the paschal lamb] be a sign to you" as "blood of the covenant and blood of the paschal lamb." The Targum, as opposed to the medieval polemic, finds only two types of blood here. In rabbinic parlance, the blood of the covenant means the blood of circumcision: see, for example, the tannaitic liturgy for conversion which specifically calls the blood of circumcision the blood of the covenant (dam brit) (Babylonian Talmud, Shabbat 137b).

The Mekhilta de-Rabbi Yishma'el, also a tannaitic text, states that at the time of the Exodus, since Israel had not yet received any commandments, it had no basis in terms of good deeds on which to be redeemed from Egypt: "God assigned to Israel two commandments, the sacrifice of the paschal lamb and circumcision which they were to perform so as to merit being saved" (Bo ch. 5). The proof text that the Mekhilta brings is from Ezekiel: "Your breasts were fashioned and your hair had grown, but you were naked (Ezek. 16: 8)." The exegete understands "naked" here to refer symbolically to "naked of all commandments." This is a startling exegetical move in which female maturation is turned into the basis for the male rite of circumcision (the text is also used to this day in the circumcision liturgy). Ezekiel also refers in the same chapter to both the blood of childbirth and menstrual blood. But 
these impure forms of female blood vanish in the rabbinic text as the blood of circumcision becomes a vehicle for redemption. Far from constructing a structuralist binary, a text such as this one eliminates the female altogether by rewriting it as male.

The blood of circumcision therefore involved a displacement of female blood into male. But where did this leave female blood in rabbinic culture? While rabbinic texts continue debating issues of ritual purity in connection with female blood, they do so in a context in which the purity regulations have become essentially theoretical. In terms of practical halakhah, female bleeding moves from the cultic to the domestic sphere, to "the regimentation of sexual relations" (Biale 158). Just as circumcision becomes a blood ritual reminiscent of the Temple sacrifices, so menstruation and childbirth are blood rituals that displace the cultic distinctions of purity and impurity to the home by dictating the rhythm of sexual relations.

Yet, here too, as in the Bible, we find no real binary between male and female blood. To be sure, in some midrashim, the origin of menstrual blood and the menstrual taboo is explained as punishment for Eve's sin:

And why are women given these commandments (niddah, hallah and the lighting of the sabbath candles)? Since our sages said that Adam was the beginning of the creation of the world and Eve came and spilled his blood ... and the Holy One Blessed Be He said: She shall be given the commandment of the blood of niddah so that it can serve as her expiation for the blood that she has spilled. (Midrash Tanhuma 1: 14b)

The blood of menstruation comes to atone for Adam's blood. As Charlotte Fonrobert argues, this follows the principle of middah ke-negged middah ("measure against measure"). It also follows logically from the punishment of childbirth for Eve's role in the expulsion from Eden. However, Eve is also punished for the death of women, as well as men, for they too become mortal as a result of her sin. So, what appears to be female bleeding as a recompense for male "bleeding" turns out to be something rather more complicated. In this midrash the issue of cultic impurity thoroughly disappears in favor of a metaphoric understanding of menstrual blood, an understanding that also has nothing to do with the blood of circumcision. 
On the other hand, the Babylonian Talmud contains a suggestion that menstrual blood might be seen as the female parallel to the blood of circumcision:

Once, the [Roman] government decreed that they [the Jews] should not observe the Shabbat, and that they should not circumcise their sons and that they should have intercourse with niddot (Meilah 17a).

To refrain from sexual relations during niddah has an equivalent weight to practicing circumcision. If the blood of circumcision became crucial, as Hoffman argues, in rabbinic literature (as it was not in biblical), then, by implication, the blood of niddah assumed similar significance. To spill the first is as essentially Jewish as to refrain from sexual contact with the second. From here, it was not a long step to the medieval polemical addition of the blood of menstruation to the other two types of blood that merited redemption.

The positive valence given to the laws of menstruation in this last statement should put us on our guard about conclusions such as Hoffman's and Eilberg-Schwartz's that the menstruating woman was seen as the embodiement of "wild nature" as opposed to the "controlled culture" of men. Both men and women - at least Jewish men and women - play their separate, but integrated, roles in Jewish culture in terms of their blood. Indeed, rabbinic texts suggest that Jewish women eagerly embraced the menstrual laws as their own. The strenuous efforts of the rabbis to elaborate a "science of blood" was a way of regaining male control over a realm of law in which women had made themselves autonomous. It is also a sign of the spiritual valence of the menstrual laws that Christian (or possibly Jewish Christian) women continued to follow them, to the consternation of male Church authorities (Fonrobert chs. 4 and 6).

\section{Blood and Xenophobia in the Kabbalah}

If neither the Bible nor rabbinic literature can be said to operate with a gendered opposition between male and female blood in the way that a number of scholars have argued, the Jewish mystical tradition does take up this distinction and maps it onto the distinction it draws between the blood of Israel and the blood of the non-Jewish nations. I will start with the blood of circumcision versus the blood of menstruation and then turn to the second bloody dyad. 
The Jewish mystical tradition went far beyond the Talmud in its negative views of the menstruant. As Sharon Koren has shown, the spurious Beraita de-Masekhet Niddah (a quasi-mystical work that she dates to the sixth or seventh centuries) contains some of the most venomous warnings about the dangers of the menstruating woman, going so far as to attribute demonic powers to her breath and her footsteps (Koren 'The Woman' 86-89). This work also argues that circumcision purifies the impure blood of childbirth (the context is the exegesis of Leviticus 12: 3). Here, we find a very strong opposition between male and female blood which would continue in the classical Kabbalah, the mystical tradition that began in the late twelfth century in Provence.

The thirteenth-century Zohar takes the rabbinic midrash that Israel was redeemed from Egypt because of the blood of the Passover sacrifice and the blood of circumcision and gives it a surprising new meaning. When one performs a circumcision, there are two types of blood. The first is that of the circumcision itself and it symbolizes the shekhinah. The second represents what is called in the circumcision ceremony periyah, the folding back of the membrane under the foreskin over the corona of the penis. This blood represents the sexual unification of the female and male divine potencies through the divine phallus. The female element of God has to be circumcised on a male body as a precondition for divine union in order to purge it of the demonic forces, represented by the foreskin. Whether or not one reads this as a masculinization of the shekhinah (Wolfson), the blood of circumcision both symbolizes and theurgically effects divine sexual union. The Zohar Hadash, a sixteenth-century collection of material not included in the printed edition of the Zohar, indirectly applies this doctrine to Abraham's circumcision (Shir ha-Shirim 4: 40). Isaac could only be born after Abraham was circumcised, that is, after Abraham shed blood. The two Hebrew letters for blood, dalet and final mem stand for elements in the lower and upper worlds that must be repaired in order to assure fertility, both human and divine. Oddly enough, the text implies that Sarah's infertility was really Abraham's!

The blood of menstruation, on the other hand, represents in the Zohar the forces of tumah or impurity. Menstruation can, in a sense, undo circumcision. The shekhinah herself is said to menstruate when she is under the sway of the demonic forces and she has "adulterous" sexual union with these forces (3: 79a, 1: 190b). Sexual relations by human beings during a woman's menstrual period can also cause the shekhinah to menstruate, which in turn causes her exile from the realm of the holy into the realm of the demonic. Isaac of Acre, a contempo- 
rary of the author of the Zohar, wrote that "the evil inclination is the primordial serpent who cast his filth upon the woman [meaning here the shekhinah] and this is the blood of menstruation" (Isaac of Acre 29) The snake is the cause of menstruation. If the "casting of filth" on the woman (the phrase comes from the Talmud) can be understood as the (male) snake ejaculating on Eve, then his ejaculated semen is the blood of menstruation, a startling convergence of contradictory fluids!

In another, especially dramatic passage in the Zohar, a snake bites the shekhinah on the vagina twice as she is giving birth. The first bite causes her to bleed and the snake licks the blood of childbirth, while the second bite causes her to emit water (the sequence of events here is, of course, the reverse of what actually happens in childbirth) (3: $249 \mathrm{~b})$. Here, it is the blood of childbirth, which is even more polluting than the blood of menstruation, that is engendered by the demonic snake. In the sixteenth century, Isaac Luria developed a complex myth of how the demonic forces crouch at the feet of the shekhinah and drink her menstrual blood (Sha'ar 35, ch. 3). To complicate matters, Luria says that these discharges come from the shekhinah's "foundation" or yesod, which, in Kabbalistic symbolism is the divine phallus. In the androgynous system of the sefirot, the male genitalia are the paradoxial source, as it were, of the shekhinah's menstrual bleeding. The demonic forces can, however, be tamed by turning the blood into preserved wine (blood and wine are often conflated in these texts, based on the biblical saying that wine is "the blood of the grape").

The Zohar also distinguishes between the blood of the nations and the blood of Israel. The Kabbalah is famously xenophobic and, one might say, even racist avant la lettre in terms of blood. The non-Jewish nations are irredeemably identified with the demonic sitra ahra and non-Jews are explicitly said to lack the spiritual souls that only the Jews possess. Basing itself roughly on Galen's physiology, the Zohar says that the liver "swallows" blood from food and then passes it on to the heart where it is spiritually refined (what Galen referred to less theologically as combination with the pneuma). The Zohar then maps this physiology onto the Jacob and Esau story (1: 138a-139a). Esau is called admoni, or ruddy, since he is associated with the blood of the liver, which is the blood of materiality. The food that he desires - red lentils - corresponds to his nature. Jacob, on the other hand, is associated with the heart, the organ that "thinks" and contains spiritual blood. The blood of Jacob or Israel is therefore in nature different from the blood of Esau. 
The Zohar, written in Christian Spain, undoubtedly had in mind the difference between Jews and Christians, since, in rabbinic typology, Esau stands first for Rome and then for Christianity. Although Moses de Leon, the author of the Zohar, lived a century before the pogroms of 1391, which are usually considered the watershed in the history of the Jews in Christian Spain, David Nirenberg and others have recently shown that even during the so-called "golden age," relations between Christians, Jews and Muslim were extraordinarily tense and sometimes violent. The Zohar's distinction between the blood of Jacob and the blood of Esau uncannily anticipates the later Spanish Christian doctrine of limpieza de sangre - or purity of the blood which was to be used against Jewish converts to Christianity and which, in turn, is often considered a precursor to nineteenth-century racial theory. As Barry Mark has suggested, racism in Spain was not a one-way street from Christians to Jews: the Kabbalah developed its own racial concepts long before the purity statutes of the mid-fifteenth century.

Following Jewish polemics of the time, the Zohar specifically associated Christianity with the pollution of menstrual blood, based on the accusations (to which we will return) that Mary conceived Jesus while she was menstruating and that Christians in general did not observe the menstrual laws. The Zohar conflated sexual relations with a nonJewish woman with sexual relations with a menstruant (3: 244a), an association that reflected the widespread miscegenation between Jews and non-Jews in Spain, or, at least, the perception by rabbinic elites that miscegenation was widespread (Assis). The author of the Zohar was particularly obsessed with this issue. By applying the language of menstrual blood pollution to relations with Christians and by arguing that it caused "the sister of God to consort with foreign gods," de Leon was using the strongest symbols at his disposal to combat a perceived social reality. Thus, the two types of blood distinctions we have traced converge: male blood - the blood of circumcision - is Jewish and female blood - the blood of menstruation - Christian. If some medieval Christian polemicists "feminized" the Jews by arguing that they menstruated, texts like the Zohar reversed the gender roles: the model of the Jew is male, the Christian female.

\section{White on the Inside and Red on the Outside}

I have suggested that the texts from the Jewish mystical tradition need to be read against the social tensions between Jews and Christians in medieval Spain. This observation brings us full circle back to the 
polemical text with which we began. The addition of menstrual blood to the blood of the paschal lamb and the blood of circumcision as types of "redemptive" blood seems remarkable, even if implicitly anticipated by the talmudic text quoted earlier. Why did our anonymous polemicist make this addition? Although canon law is ambiguous and, at times, contradictory on the question of whether Christian women should observe menstrual abstinence (Brundage 53, 91-92, 156, 199, $242,283,451,508)$, Ashkenazic Jews believed that one of the sharpest distinctions between themselves and their Christian neighbors was the menstrual laws. In many of the bitter polemics against Christianity, such as the Hebrew chronicles of the Crusades, Jesus is pilloried as "a bastard son conceived by a menstruating and wanton mother" (Eidelberg 32) What was true for Mary (no Virgin here!), was true for all Christian women. One of the most remarkable texts from the polemical literature asks the astonishing question "why are most Christians fair-skinned and beautiful while Jews are dark and ugly?" (Berger 224) The Jewish polemicist evidently accepts a Christian standard of beauty in his very posing of the question. One is instructed to answer such Christian arguments as follows:

...this is similar to a fruit; when it begins to grow it is white but when it ripens it becomes black, as is the case with sloes and plums. On the other hand, any fruit which is red at the beginning becomes lighter as it ripens, as is the case with apples and apricots. This, then, is testimony that Jews are pure of menstrual blood so that there is no initial redness. Christians, however, are not careful about menstruant women and have sexual relations during menstruation; thus, there is redness at the outset, and so the fruit that comes out, i.e., the children, are light. (Berger 224)

In other words, external appearance actually conceals its opposite and the very fairness of Christians gives away their impure origins.

Precisely because of this abhorrence of presumed Christian practice, Jews insisted that their own practices produced purity. Morever, in answer to the "proto-feminist" Christian claim that both men and women are equally redeemed by the water of baptism, the Jews might answer:

The heretics ask: We baptize both males and females and in that way we accept our faith, but in your case only men and 
not women can be circumcised. One can respond: Women are accepted because they watch themselves and carefully observe the prohibitions connected with menstrual blood (Berger 224).

The virtue of Jewish women is connected here and elsewhere with their avoidance of menstrual blood, which confers the same salvation as the blood of circumcision. And, it is blood, not water, that is the Jewish agent of salvation: "So you see that blood is better than water, as it is written, 'Live in your blood' (Ezekiel 16: 6)" (Berger 224). This evocation of the verse from Ezekiel about female blood, which had come since rabbinic literature to mean the blood of circumcision, now regained some of its original signification: blood from the female genitals as a divine fluid. Finally, it should not escape our notice that this Jewish appropriation of male and female blood as the agents of salvation must have been a conscious subversion of the Christian notion of redemption through the blood of Christ.

Medieval Jewish culture certainly regarded menstrual blood as negative, even demonic. But as the polemical texts suggest, the very power of the menstrual taboo opened the door to a surprising equivalence between circumcision and menstruation. Just as men had a ritual whose blood might be redemptive, so women, in following the strictures of the menstrual laws, had their rituals of redemption which were connected to female blood. In this way, what I have suggested as the original biblical meaning of menstrual blood, as a bodily fluid issuing from a divine source, enjoyed a surrepetitious afterlife in a later cultural context. And the tradition of reading Ezekiel 16 as referring to both male and female blood created a gender "fluidity" that implicitly subverted the antinomy between them. Blood certainly had gendered meanings in all these strata of Jewish culture, but they were meanings more complicated and unexpected than the theories of contemporary anthropologists of Judaism might allow.

\section{Works Cited}

Archer, Leonie. "Bound By Blood: Circumcision and Menstrual Taboo in Post-exilic Judaism" Ed. Janet Martin Soskice. After Eve: Women, Theology and the Christian Tradition. London: Marshall Pickering, 1990: 38-61.

Assis, Yom Tov. "Sexual Behaviour in Mediaeval Hispano-Jewish 
Society." Ed. Ada Rapoport-Albert and Steven J. Zipperstein. Jewish History: Essays in Honour of Chimen Abramsky. London: P. Halban, 1988: 25-60.

Babylonian Talmud.

Berger, David. The Jewish-Christian Polemic in the Middle Ages. Philadelphia: Jewish Publication Society, 1979.

Biale, Rachel. Women in Jewish Law. New York: Schoken Books, 1984.

Brundage, James A. Law, Sex and Christian Society in Medieval Europe. Chicago: University of Chicago Press, 1987.

Buber, Solomon, ed. Midrash Tanhuma. Jerusalem: Ortsel, 1964.

Cook, Leslie A. "Body Language: Women's Rituals of Purification in the Bible and Mishna." In Rahel R. Wasserfall ed. Women and Water: Menstruation in Jewish Life and Law. Hanover: University Press of New England, 1999: 40-59.

Douglas, Mary, Purity and Danger. London: Ark, 1966.

Eidelberg, Shlomo, ed.. The Jews and the Crusaders: The Hebrew Chronicles of the First and Second Crusade. Madison: University of Wisconsin Press, 1977.

Eilberg-Schwartz, Howard. The Savage in Judaism. Bloomington: Indiana University Press, 1990.

Fonrobert, Charlotte Elisheva. Menstrual Purity. Stanford: Stanford University Press, 2000.

Hoffman, Lawrence A. Covenant of Blood: Circumcision and Gender in Rabbinic Judaism. Chicago: University of Chicago Press, 1996

Isaac of Acre. Sefer Me'irat Einayim. Lugano: Erlanger, 1975.

Jay, Nancy. Throughout Your Generations Forever: Sacrifice, Religion and Paternity. University of Chicago Press: Chicago, 1992.

Jerusalem Talmud.

King, Helen. Hippocrates' Woman: Reading the Female Body in Ancient Greece. London: Routledge, 1998.

Koren, Sharon, "Mystical Rationales for the Laws of Niddah." In Rahel $\mathrm{R}$. Wasserfall ed. Women and Water: Menstruation in Jewish Life and Law. Hanover: University Press of New England, 1999: 101-121.

-. 'The Woman from whom God Wanders: ' The Menstruant in Medieval Jewish Mysticism." New Haven: Yale University doctoral dissertation, 1999.

Levine, Baruch. Leviticus. Philadelphia: Jewish Publication Society, 1989.

Luria, Isaac. Etz Hayyim. Jerusalem: Vitbetsky, 1988.

Maccoby, Hyam. Ritual and Morality: The Ritual Purity System and its Place in Judaism. Cambridge: Cambridge UP, 1999. 
Mark, Barry. "Kabbalistic Tocinofobia: Americo Castro, Limpieza de Sangre, and the Inner Meaning of Jewish Dietary Laws." Fear and its Representation in the Middle Ages and the Renaissance. Arizona Studies in the Middle Ages and the Renaissance, no. 6. Turnhout, Belgium: Brepols Publishers, forthcoming.

Meigs, Anna S. Food, Sex, and Pollution: A New Guinea Religion. New Brunswick: Rutgers UP, 1984.

Mekhilta de-Rabbi Yishma'el. Jerusalem: Bamberger, 1960.

Milgrom, Jacob. The Anchor Bible: Leviticus 1-16. New York: Doubleday, 1991.

一. The Anchor Bible: Leviticus 17-22. New York: Doubleday, 2000.

Nirenberg, David. "Conversion, Sex, and Segregation: Jews and Christians in Medieval Spain." American Historical Review. 107 (October 2002): 1065-1093.

-. Communities of Violence: Persecution of Minorities in the Middle Ages. Princeton: Princeton University Press, 1996.

Ortner Sherry B., "Is Female to Male as Nature Is to Culture?" Ed. Michelle Zimbalist Rosaldo and Louise Lamphere. Women, Culture and Society. Stanford: Stanford University Press, 1974. 67-88.

Sefer ha-Zohar. Jerusalem: Ahuzat Yisrael, 1962

Wasserfall, Rahel R., ed. Women and Water: Menstruation in Jewish Life and Law. Hanover: University Press of New England, 1999.

Wolfson, Elliot R.. Circle in the Square: Studies in the Use of Gender in Kabbalistic Symbolism. Albany: SUNY Press, 1995.

Zohar Hadash. Jerusalem, 1965. 